\title{
Culture and employee performance: The mediating role of personality and commitment
}

\author{
Olivia Laura Sahertian ${ }^{a^{*}}$, Margono Setiawan ${ }^{\mathrm{b}}$ and Sunaryo $^{\mathrm{b}}$
}

${ }^{a}$ Student/Program Doctoral of Management science, Brawijaya of University Malang., Indonesia ${ }^{b}$ Lecturer/Faculty of Economics and Business, Brawijaya of University Malang., Indonesia

C H R O N I C L E

\begin{tabular}{l}
\hline Article history: \\
Received: November 3, 2019 \\
Received in revised format: No- \\
vember 282019 \\
Accepted: December 3, 2019 \\
Available online: \\
December 4, 2019 \\
\hline Keywords: \\
Culture \\
Employee performance \\
Work commitment \\
Nurse \\
Maluku \\
Indonesia
\end{tabular}

\section{A B S T R A C T}

\begin{abstract}
This research aimed to analyze and explain the role of the Pela Gandong culture in Maluku in improving the performance of hospital nurses in Maluku, Indonesia, through the mediation of personality and work commitment. This research used a survey method with a quantitative approach. The study was conducted at general hospitals in Maluku, Indonesia by involving 189 respondents and the analytical tool used was SEM-PLS. The results showed that the Pela Gandong culture influenced personality and work commitment but had no effect on employee performance. Meanwhile, personality and work commitment had an effect on employee performance. Thus, both personality and work commitment mediated the effect of the Pela Gandong culture on employee performance. Interestingly, the Pela Gandong culture had no effect on employee performance. However, through the mediation of personality and work commitment, the Pela Gandong culture could affect employee performance.
\end{abstract}

(C) 2020 by the authors; licensee Growing Science, Canada

\section{Introduction}

Good performance is a fundamental goal for an organization (Soane et al., 2015) and becomes an important issue today (Mandagi et al., 2015). Unpredictable business environmental development demands organizations to achieve certain standards by improving performance (Muda et al., 2014). Performance relates to individuals or human resources which are the determinant in achieving organizational goals (Muda et al., 2014). In these recent decades, the quality and performance of health organizations have received much attention in many countries (Mannion et al., 2005). The implementation of MEA in Southeast Asia creates a free flow of goods, services, investments, and educated workforces from and to each country. The health sector is one of the service sectors included in the MEA implementation so that capacity strengthening and development are highly needed in this sector. The health sector in Indonesia is still very weak. It can be seen from health personnel in hospitals, clinics, and others. Health personnel policy planning is also considered weak and the quality of the results of health personnel education and training is even generally not optimal (Mahdi, 2014). Hospitals as health care providers face many challenges and must still continue to provide the best service to patients. The quality of services provided to the public can be reflected in the good attitudes and behavior of employees (Bellou, 2008). The application of good human resource management is meant to create efficiency and innovation, respond to patient needs, and realize service quality excellence. Medical personnel in hospitals are individuals who function as a driving force and strongly determine hospital progress. In general speaking, individuals are inseparable from behavior. Based on the social cognitive theory, individuals will behave and act accordingly to their daily values, beliefs, and social habits. Individuals have the strength and ability to regulate themselves based on values they believe to be good and true which are controlled by biological and environmental forces. The social cognitive theory also sees that individuals have self-beliefs that allow them to control thoughts, feelings, and actions taken. * Corresponding author.

E-mail address: oliviasahertian@yahoo.com (O.L. Sahertian) 
One of the values existing in society is cultural values. Culture is very interesting to be explored further in the study of organizational behavior (Aponno, 2017). Indonesia is a country known for its diverse cultures, ethnic groups and languages, which is wealth. Each region in Indonesia has diverse and unique cultural local wisdom. Maluku is one of the provinces in Indonesia that has historical values for the Indonesian people. Indonesia's natural wealth in the form of spices can attract other countries. Maluku has a culture called Pela Gandong. Pela can be interpreted as a bond between two or several villages and Ganding can be interpreted as a bond of blood brotherhood. This local culture of Maluku (Pelo Gandong) reflects the values of love, honesty, trust, and justice. The Pela Gandong culture variable is a new variable that distinguishes this research from previous studies and shows the originality of this research. Some studies on the influence of local culture on performance have been conducted by Lin and Zhao (2016), Ngo dan Li (2015), Burke (1995), Liu et al. (2013) and prove that culture influences performance. Rante (2010) and Kambu et al. (2012) found that local culture had no effect on performance.

In previous decades, organizations saw individual personalities in the process of employee recruitment. However, nowadays, there is a paradigm shift about individual personalities related to organizational goals (Wu et al., 2011). Culture influences individuals personally and relates to one's personality in general (Martinez \& Oishi, 2006; Triandis \& Suh, 2002). Personalities are related to individuals. Individual differences are prioritized in the management science and organizational behavior for an important reason, namely the direct effect of individual differences on behavior (Ivancevich, 2011). Personality is extremely necessary for determining employee performance and is an important antecedent of performance (He et al., 2015). Personality will influence individual behavior (Yang \& Hwang, 2014). Research that proves personality influences performance is conducted by Yang and Hwang (20140, Bhatti (2014), He et al. (2015), and Rashid et al. (2016). Talking about attitudes in organizational behavior, commitment is one of the individual attitudes. Work commitment is a major predictor and determinant of performance (Cohen, 2006). Commitment, especially in terms of loyalty and efficiency, is an important thing in organizations (Berberoglu \& Secim, 2015). Commitment is the ability and willingness to harmonize personal behavior with organizational needs, priorities, and goals. Commitment has an important role, especially in individual work performance. Research that proves that commitment affects performance is conducted by Berberoglu and Secim (2015), Tolentino (2013) and (Kashefi et al., 2013). The phenomena and the facts show that hospitals still face a lot of problems, such as lack of HR commitment, organizational system inconsistency, different perceptions of service quality, limited funds, low entrepreneurial spirit and work culture, and the presence of negative stigma in society about the image and quality of hospitals in Indonesia (Widajat, 2009). Based on the above explanation about the weaknesses of medical personnel in administering health services in Indonesia, there are several facts in Maluku proving patient dissatisfaction with the performance of medical personnel in providing health services. Many complaints are expressed by the community towards hospital medical services. In this regard, this research was conducted to examine the role of culture in improving nurse performance with the mediation of personality and work commitment.

The purpose of this research is to analyze and explain the role of the Pela Gandong culturein Maluku in improving the performance of hospital nurses in Maluku, Indonesia, through the mediation of personality and work commitment. This research contributes to the relationship between culture and individuals in an organization to achieve good performance by focusing on the local culture of Pela Gandong in Maluku, Indonesia. The empirical evidence will be presented to illustrate the effect of the Pela Gandong culture on employee performance mediated by personality and work commitment.

\subsection{Empirical Studies}

Child dan Warner (2003) revealed that Chinese culture is influenced and shaped by Confucius teachings that have a considerable effect on the lives of Chinese people. Taoist teachings greatly influence and shape Chinese culture. Furthermore, Lin and Zhao (2016), Ngo \& Li (2015)and Liu et al. (2013) studied the effect of Chinese culture on individual performance and career in China. A study on Canadian culture conducted by Burke (1995) also proved that culture highly influences individual performance. Differently, in Indonesia, Kambu et al. (2012) studied the local culture of Papua and found that the Papuan culture had a negative effect on performance while another study conducted by Rante (2012) suggested that the Papuan culture had no effect on performance. Similarly, Anisah (2011) found that Banjar culture did not affect performance. Thus, this research gap was needed to be further examined in this research. Yang dan Hwang (2014), Bhatti (2014), He et al. (2015), and Rashid et al. (2016) proved that personality had an effect on performance. Personality is an important factor from individuals that can affect performance and is very appropriate in mediating employee performance (He et al., 2015). Personality plays an important role in achieving organizational success. Berberoglu and Secim (2015) and Wahyuni (2008) proved that there is a significant and positive relationship between organizational commitment and medical personnel performance in hospitals. Likewise, Tolentino (2013) and Kashefi et al. (2013) also found that commitment significantly and positively influences performance.

\section{Literature review and hypotheses development}

\subsection{Employee Performance in Organization}

Performance is interpreted as a work result or achievement. Performance is the manifestation of work done by someone (Robbins, 2008; Gibson et al., 2015). According to Gibson et al. (2015), performance is the extent to which a person is 
successful in doing his work. Performance can be further defined as a record of results of production and work or certain activities, one of which is the balance between workers and the surrounding environment including individuals, resources, work clarity, and feedback (Gibson et al., 2015). Individual performance is the basis of organizational performance. Individuals who have a strong commitment to achieving good performance can ultimately improve organizational performance. Related to performance, the Goal-Setting Theory is the basis that can point individual commitment towards goals. That is, the decision not to ignore goals is on the hand of each individual himself. Based on this explanation, individuals can achieve both individual and organizational goals that have been stated. In using the Goal-Setting Theory, employee performance is the goal to be achieved while the variables of local culture, personality, and work commitment are determinants. Performance is the dependent variable in this study and hereinafter referred to as endogenous variables.

\subsection{Introduction of "Pela Gandong"}

The cultural aspect is one of the pillars of national resilience (Uneputty, 1996). Culture is an abstraction of individual behavior. Culture becomes an important factor in influencing individuals to behave. Community culture and organizational culturerun together may influence a person's values, ethics, attitudes, and expectations (Kreitner \& Kinicki, 2014). The national culture of a country is the crystallization of local cultural values. Indonesia is rich in culture. Local culture is the identity of the Indonesian people. Maluku - an inseparable part of Indonesia - is known as the area of a thousand islands which is rich in spices. Historically, Maluku is the oldest province in Indonesia, proven from a record of clay found in Persia, Mesopotamia, and Egypt. The record of clay mentions the existence of a very rich country from the east, a land of heaven with various natural products such as nutmeg, cloves, gold and pearls. One culture hereditarily applied in the life of Maluku people is Pela Gandong. The custom or tradition of Pela Gandong is a cultural heritage of the people of Central Maluku, especially Seram Island, Ambon and Lease Islands (Sahusilawane, 2004). The Pela Gandong tradition is meant to strengthen the bond of brotherhood. Pela is interpreted as a bond of brotherhood between two or more countries (villages) while Ganding is interpreted as a brotherly relationship between two or more countries (villages) based on or backgrounded by genealogic relations, in which ancestors of these villages came from the same descendants (Uneputty, 1996). Local culture Maluku pela gandong is the dependent variable in this study and hereinafter referred to as exogenous variables. Amaliah (2014) in her study explained 4 values contained in Pela Gandong, namely love, honesty, trust, and justice. These values would be used as indicators of the Pela Gandong local culture in this research.

\subsection{Personality}

Personality structures are developed through research and aim to identify characteristics that describe a person's behavior. The stronger and more consistent the characteristics occur in various situations, the more important it will be in describing the individual's personality. Personality refers to how people influence others, how they understand and perceive themselves, and how the patterns of their inner and outer characters measure trait and interactions between humans in every situation. Psychologically, there is a connection between culture and personality (Uneputty, 1996). In the $20^{\text {th }}$ century, there have been many studies of culture and personality. The approach used to understand the relationship between culture and personality is called cultural psychology. This view suggests that culture influences personality (Gea, 2010). Personality is mediating variable in this study.

\subsection{Work Commitment}

The concept of commitment arises from studies exploring the link or relationship between employees and the community. Commitment is a loyal behavior in organizations and is a continuously ongoing process shown by individuals (Kashefi et al., 2013). Commitment in the workplace is important to understand as employee behavior and performance. Commitment becomes a major predictor of individual behavior, just as actual performance, $O C B$, turnover, and absenteeism (Cohen, 2007). The typology of work commitment was put forward by Becker and Carper in 1965, grounded on the concept of professionalism which is broadly related to individuals with their professions. This development is based on the Side-Bet Theory with two main focuses, namely organization and job. Meyer et al. (1993) developed a three-component model of work commitment, consisting of affective work commitment, continuous work commitment, and normative work commitment. Affective work commitment refers to the psychological attachment of employees to their work due to their own desire. Continuous work commitment refers to the calculation of profit and loss received by an employee in connection with his willingness to survive or quit his job due to their needs. Normative work commitment refers to an obligation for employees to stay on the job because they have to. Work commitment is mediating variable in this study.

\subsection{Hypothesis}

Today's modern people of China are shaped from strong history and culture (Child \& Warner, 2003; Rarick, 2007). Similarly, culture in Japan also influences organizations (Chang, 2007; Teasdale, 1999). Empirical studies examining the effect of culture on performance conducted by Liu et al. (2013), Ngo and Li (2015) and Lin and Zhao (2016) showed that culture had an effect on performance. Thus, the researcher formulated this following hypothesis. 
H1a: The Pela Gandong Culture has an effect on Employee Performance.

The effect of culture on personality becomes a concern and research object for psychologists and researchers. Culture is the main determinant of individuals (Martinez \& Oishi, 2006). A study conducted by Volkema and Fleck (2012) suggests that culture influences personality. Thus, the following hypothesis can be proposed.

H1b: The Pela Gandong Culture has an effect on Personality.

Culture is an interesting matter to be further investigated. Culture is an important factor influencing individual behavior (Matsumoto, 2007). Commitment is influenced by many factors, one of which is cultural values (Kwantes, 2009). Kwantes (2009) and Baumanis, 2002 proved that culture influences commitment. Thus, the researcher formulated this following hypothesis.

H1c: The Pela Gandong Culture has an effect on Work Commitment.

Individual personalities are diverse in an organization. The diverse personalities become both a wealth and a challenge for the organization. Individuals who have an open personality tend to be more open about their experience and curiosity, appreciate art and beauty values, creative and more conservative (Robbins, 2008). Rashid et al. (2016), Bhatti et al. (2014), He et al. (2015) and Abdullah et al. (2013) found that personality has an effect on performance. Thus, the following hypothesis can be formulated.

H2a: Personality has an effect on Employee Performance.

Individuals with high commitment and loyalty will have good behavior and can improve performance (Berberoglu \& Secim, 2015; Tolentino, 2013, Kashefi et al., 2013). Employees who are committed and loyal to their jobs will improve their job performance. Based on this explanation, the following hypothesis can be formulated.

H2b: Work Commitment has an effect on Employee Performance.

Culture is inseparable from the development of traits and adaptations, leading to personality disclosures (Gea, 2010; Schaller \& Murray, 2008). Empirical studies conducted by Abdullah et al. (2013), Bhatti et al. (2014), He et al. (2015) and Rashid et al. (2016) suggest that personality has an effect on performance. Thus, the researcher proposed this following hypothesis.

H3a: Personality mediates the effect of the Pela Gandong Culture on Employee Performance.

Culture can basically affect personality through social structures and social systems existing in a particular environment. Culture also influences performance (Lin \& Zhao, 2016; Ngo \& Li, 2015).Commitment is a major predictor of performance, empirically proved by Tolentino (2013), Kashefi et al. (2013), Berberoglu and Secim (2015)and Widyaningrum (2012). Based on the above description, the following hypothesis can be formulated.

H3b: Work commitment mediates the effect of the Pela Gandong Culture on Employee Performance.

\section{Methodology}

This research was explanatory research using a survey method with a quantitative approach. This research aimed to analyze and explain the influence of the Pela Gandong culture on employee performance mediated by personality and work commitment. The Pela Gandong culture was the exogenous variable while employee performance was the endogenous variable. The mediating variables were personality and work commitment. The respondents in this research were nurses at general hospitals in Maluku Province. The respondent selection was based on the criteria of being permanent nurses and having worked for more than 5 years. The sampling was done using a proportionate random sampling. The respondent samples involved were 225 nurses, but the questionnaires that were successfully returned and valid to be further processed were only 189 questionnaires. The data were analyzed descriptively by illustrating the respondent identity data with their answer choices on questionnaires. Moreover, an inferential analysis was also conducted with SEM-PLS.

\subsection{Measurement}

Questionnaires were used to collect the data for this research. The Pela Gandong Culture variable was measured using 4 indicators, namely love, honesty, trust, and justice, through 10 question items. The Personality variable was measured using the Big Five (5 indicators), namely extraversion, agreeableness, conscientiousness, emotional stabilityandopenness to experience, through 18 question items. As for the Work Commitment variable, it was measured using 3 indicators developed by Meyer et al. (1993), consisting of affective work commitment, continuous work commitment, and normative work commitment, through 18 question items. These three variables were measured using a Likert scale with 5 alternative options ( $5=$ Strongly Agree, 4= Agree, 3= Less Agree, 2= Disagree, 1= Very Disagree). The Employee Performance variable was 
measured by factual data in the form of Employee Work Targets referring to Government Regulation No. 46 of 2011 , Decree of the Minister of Health No. 836 of 2005 and Regulation of Ministry of Empowerment of State Apparatus and Bureaucracy Reform No. 25 of 2014).

\section{Results}

\subsection{Hypothesis Testing}

Convergent validity, discriminant validityandcomposite reliability were used to assess the outer model. Based on the results of SEM-PLS analysis, convergent validity was seen from the loading factor value of $>0.7$. It indicates that the $t$-statistic and $\mathrm{t}$-count values were greater than the t-table value. Thus, no indicator was discarded. Discriminant validity shows the validity of variables. As can be seen in Table 1, the $A V E$ values of the three variables were $>0.5$. Composite reliability aims to measure the reliability of research variables. As shown in Table 1, the Composite Reliability and Cronbach's Alpha values of the three variables were $>0$. These values indicate that all variables were valid and reliable.

Table 1

Values of Composite Reliability, Cronbach's Alpha, and AVE

\begin{tabular}{cccc}
\hline Variable & Composite Reliability & Cronbach's Alpha & AVE \\
\hline Culture & 0.917 & 0.879 & 0.735 \\
Personality & 0.935 & 0.913 & 0.741 \\
Work Commitment & 0.927 & 0.882 & 0.809 \\
\hline
\end{tabular}

Structural model testing was done through the R-Square $\left(\mathrm{R}^{2}\right)$ value for the dependent variable and through the Stone-Geisser $\mathrm{Q}-$ Square $\left(\mathrm{Q}^{2}\right)$ for the predictive relevance. The $\mathrm{R}^{2}$ value of the personality variable was 0.272 , meaning that the local culture variable contributed to the personality variable of $27.2 \%$. The $\mathrm{R}^{2}$ value of the commitment variable was 0.345 , indicating that the local culture variable had an effect on the commitment variable of $34.5 \%$. The $\mathrm{R}^{2}$ value of the performance variable was 0.521 , signifying that the local culture, personality, and work commitment variables contributed to the performance variable of $52.1 \%$. The Q-Square $\left(\mathrm{Q}^{2}\right)$ was determined using the following formula:

$\mathrm{Q}^{2}=1-\left(1-\mathrm{R} 1^{2}\right)\left(1-\mathrm{R} 2^{2}\right)\left(1-\mathrm{R}^{2}\right)=1-(1-0.272)(1-0.345)(1-0.521)=0,772$

As resulted from the calculation, the $\mathrm{Q}^{2}$ value reached 0.772 or $77.2 \%$, meaning that this research model was feasible and said to have a relevant predictive value, explaining $82 \%$ of the overall information. The hypothesis testing used a t-test or significance test of the structural path parameter coefficient obtained from the bootstrapping procedure. Table 2 below presents the testing results of direct and indirect effects. The testing results of H1a showed a t-statistic value of 1.825 with a path coefficient value of 0.117 . That is, the Pela Gandong culture had no effect on employee performance, so H1a was rejected. As for $\mathrm{H} 1 \mathrm{~b}$, the t-statistic value reached 10.253 with a path coefficient value of 0.522 . That is, the Pela Gandong culture had a significant and positive effect on personality, so H1b was accepted.

Table 2

Testing Results of Direct and Indirect Effects

\begin{tabular}{|c|c|c|c|c|c|c|c|}
\hline \multicolumn{5}{|c|}{ Direct Effect } & \multicolumn{3}{|c|}{ Indirect Effect } \\
\hline $\begin{array}{c}\text { Independent } \\
\text { Variable }\end{array}$ & $\begin{array}{c}\text { Dependent } \\
\text { Variable }\end{array}$ & $\begin{array}{c}\text { Path } \\
\text { Coefficient }\end{array}$ & t-Statistics & Des. & Variable Relationship & $\begin{array}{c}\text { Indirect Effect } \\
\text { Coefficient }\end{array}$ & Des. \\
\hline $\begin{array}{l}\text { Pela Gandong } \\
\text { Culture }\end{array}$ & $\begin{array}{c}\text { Employee } \\
\text { Performance }\end{array}$ & 0.117 & 1.825 & $\begin{array}{c}\text { Not } \\
\text { Significant }\end{array}$ & \multirow{3}{*}{$\begin{array}{c}\text { Pela Gandong } \\
\text { Culture } \rightarrow \text { Personality } \\
\rightarrow \\
\text { Performance }\end{array}$} & \multirow{3}{*}{0.147} & \multirow{3}{*}{ Significant } \\
\hline $\begin{array}{c}\text { Pela Gandong } \\
\text { Culture }\end{array}$ & Personality & 0.522 & 10.253 & Significant & & & \\
\hline $\begin{array}{c}\text { Pela Gandong } \\
\text { Culture }\end{array}$ & $\begin{array}{c}\text { Work } \\
\text { Commitment }\end{array}$ & 0.587 & 12.342 & Significant & & & \\
\hline Personality & $\begin{array}{c}\text { Employee } \\
\text { Performance }\end{array}$ & 0.281 & 4.871 & Significant & \multirow{2}{*}{$\begin{array}{c}\text { Pela Gandong } \\
\text { Culture } \rightarrow \text { Work } \\
\text { Commitment } \rightarrow \text { Perfor } \\
\text { mance }\end{array}$} & \multirow{2}{*}{0.248} & \multirow{2}{*}{ Significan } \\
\hline $\begin{array}{c}\text { Work } \\
\text { Commitment }\end{array}$ & $\begin{array}{c}\text { Employee } \\
\text { Performance }\end{array}$ & 0.423 & 7.534 & Significant & & & \\
\hline
\end{tabular}

Likewise, the testing results of the H1c showed a t-statistic value of 12.342 with a path coefficient value of 0.587 . It indicates that the Pela Gandong culture significantly and positively affected work commitment, so H1c was accepted. Based on the findings of this research, H2a was also accepted, proved by a t-statistic value of 4.871 with a path coefficient value of 0.281 . That is, personality had a significant and positive effect on employee performance. Similarly, H2b stating that work commitment has a significant and positive effect on employee performance was accepted by reaching a t-statistic value of 7.534 with a path coefficient value of 0.423 . Furthermore, the researcher found that the testing results of $\mathrm{H} 3 \mathrm{a}$ resulted in a path coefficient value of 0.147 . In other words, H3a stating that personality mediates the effect of the Pela Gandong culture on employee performance was accepted. The personality variable perfectly mediated the effect of the Pela Gandong culture 
on employee performance. Similarly, H3b stating that work commitment mediates the effect of the Pela Gandong culture on employee performance was also accepted, indicated from the path coefficient value of 0.248 . The work commitment variable also perfectly mediated the effect of the Pela Gandong culture on employee performance.

\section{Discussion}

The values contained in culture can influence organizational behavior (Hosftede, 1991). Cultural values can improve the performance of health organizations (Mallak, et al., 2006). The purpose of this research was to analyze the effect of culture on the performance of nurses in hospitals by using personality and work commitment as mediating variables. The culture studied in this research was the local culture of Pela Gandong existing in Maluku, Indonesia. The culture variable was measured using 4 indicators, namely honesty, trust, and justice, which are important things that must be owned and practised by nurses in hospitals. The interesting part of this research is that the culture had no effect on employee performance. This is in line with the studies conducted by Rante (2010), Anisah (2011) and Kambu et al. (2012) and in contrast with the studies conducted by Liu and Liu (2013), Ngo and Li (2015) and Lin and Zhao (2016). Besides, the results of this research reinforce the arguments of Atmosoeprapto (2001) that some elements of culture existed and formed in an organization were determined by the environment where the organization operates; values were basic concepts and organizational beliefs; people become a role model due to their success; ceremonies including routine events held by organizations are intended to reward employees, and; information communication network in organizations can be a means of disseminating cultural values. Furthermore, the findings of this research are also consistent with the concept of Robbins (2008) stating that employee performance is a function of the interaction between Ability (A), Motivation (M) and Opportunity $(\mathrm{O})$; or Performance $=\mathrm{f}(\mathrm{A} \times \mathrm{M} \times \mathrm{O})$. High performance is a function of the absence of controlling obstacles for individuals in the organization. An individual cannot have high performance if there are significantly hampering obstacles even though he is actually willing and able to perform well. Based on the characteristics of the respondents, some of the nurses worked for less than 5 years. This certainly influences the understanding and application of pela gandong local culture. Those who work for less than 5 years and are not native Moluccas have very little information and poor understanding about pela gandong culture.

The research findings also give evidence that culture influences personality. It means that culture influences individuals personally and generally related to one's personality (Martinez \& Oishi, 2006; Triandis \& Suh, 2002). This is in accordance with Martinez dan Oishi (2006) suggesting that personality is formed due to genetic and environmental factors, but the most influencing factor is culture. Thus, it can be said that culture is an important factor in shaping individual personality. Moreover, the research findings also indicate that culture also influences work commitment. This supports the studies of Baumanis (2002), Lemaster (2003), and Kwantes (2009). Commitment is influenced by many factors, one of which is cultural values (Kwantes, 2009). Furthermore, the results of this research also suggest that personality has a significant and positive effect on employee performance. This is linear with previous results of Yang and Hwang (2014), He et al. (2015), Abdullah et al. (2013), Bhatti et al. (2014), Abdullah et al. (2013), Cartaya (2012), Ahmad et al., 2014 and Krawjeski et al., 2007. Individuals with stable emotions and openness will tend to have better performance (He et al., 2015). The results of this research also show that work commitment affects employee performance, supporting previous results of Berberoglu \& Secim (2015), Kalkavan and Katrinli (2014) andWidyaningrum (2012). This opinion is barely distinguishable from Meyer et al. (1993) stating that commitment is the one's dedication to other people, work, and organization by intending to stay on what becomes his loyalty. Furthermore, work commitment can be defined as a major predictor and determinant of performance (Cohen, 2006). Based on the results of the respondents' answers, the average value for the indicator of the personality variable was very good. Nurses who work in hospitals had good personalities and they were happy to meet other people, sympathetic, friendly and kind, work well and are organized, have stable emotions, are not easily offended and creative. Good personality of the nurse must be developed in order to support the behavior and attitude of the nurse at work.

Personality is a variable perfectly mediating the effect of culture on employee performance. Cartaya (2012) argued that the relationship between personality and performance can be either direct or indirect. Personality is an important thing related to human nature, which can affect organizations and improve individual performance (Liguori et al., 2013). The results of this research also indicate that work commitment also mediates perfectly the effect of culture on employee performance. Steers (1980) defined organizational commitment as a sense of identification (trust in organizational values), involvement (willingness to try as best as possible in the interests of the organization), and loyalty (the desire to remain a member of the organization). This finding is reinforced by a descriptive analysis that the average is good, which has a high work commitment. Based on respondents' answers, itNurse's work commitment must be increased. Nurses who have a high commitment have high loyalty and a tendency to do the best in carrying out their work and provide the best for the hospital. can be identified that nurses in hospitals in Maluku Province are nurses who are proud and happy at their jobs as nurses, passionate about work, choosing jobs as nurses, responsible for work and having high loyalty.

\section{Conclusion}

The results of this research found that Maluku local culturepela gandong had no effect on employee performance. Local culture influences personality and work commitment, personality affected performance and work commitment affected performance too. Through the mediation of personality and work commitment, the Pela Gandong culture finally had an effect 
on performance. Work commitment had the greatest mediation role. Commitment was a condition where organizational members were very interested in the goals, values, and objects of their organization. A similar opinion was also stated by Cohen (2006) that work commitment was the main determinant of performance.

\section{Acknowledgement}

The authors would like to thank the following people and organizations for supporting this paper.

Directorate General of Higher Education, Ministry of Research, Technology and Higher Education of the Republic of Indonesia

$>$ The promoter team of the Management Science Doctoral Program at the Faculty of Economics and Business, Brawijaya University, Indonesia

$>$ State Polytechnic of Ambon, Maluku, Indonesia

$>$ Head of hospital and staff of Dr. Haulussy and Prof. J. A Latumeten Level II Hospital in Maluku Province, Indonesia.

\section{References}

Abdullah, I., Rashid, Y., \& Omar, R. (2013). Effect of Personality on Job Performance of Employees : Empirical Evidence from Banking Sector of Pakistan. Middle-East Journal of Scientific Research, 17(12), 1735-1741.

Ahmad, J., Ather, M. R., \& Hussain, M. (2014, June). Impact of Big Five personality traits on job performance (Organizational commitment as a mediator). In Management, knowledge and learning international conference (pp. 25-27).

Amaliah, T. R. I. H., Doktor, P., Akuntansi, I., Ekonomi, F., Bisnis, D. A. N., \& Brawijaya, U. (2014). DALAM LINGKUP NILAI-NILAI BUDAYA.

Anisah, H. U. (2008). Peran Budaya Banjar dalam Meningkatkan Kinerja dan Keunggulan Bersaing melalui Kewirausahaan Islami dan Strategi ( Studi pada Industri Kecil Menengah Batu Muliamermata di Martapura Kalimantan Selatan ), (2003).

Aponno, E. H. (2017). Budaya Lokal Maluku “ Pela Gandong” Dalam Konteks Perilaku. Jurnal Manajemen, 03(01), 12-25.

Awais Bhatti, M., Mohamed Battour, M., Rageh Ismail, A., \& Pandiyan Sundram, V. (2014). Effects of personality traits (big five) on expatriates adjustment and job performance. Equality, Diversity and Inclusion: An International Journal, 33(1), 73-96.

Baumanis, L. (2002). Information to users.

Bellou, V. (2008). Identifying organizational culture and subcultures within Greek public hospitals. Journal of Health, Organisation and Management, 22(5), 496-509.

Burke, R. J. (1995). Culture' s consequences: organizational values, satisfaction and performance. Empowerment in Organizations, 3(2), 19-24.

Cartaya, E. (2012). Personality and performance: Assessing the mediating role of mental model formation in the personalityperformance relationship.

Chang, L., \& Business, I. (2007). A Study on Japanese Culture and Styles of Business Negotiation. Culture.

Child, J., \& Yan, Y. (2003). Predicting the performance of international joint ventures: An investigation in China. Journal of Management Studies, 40(2), 283-320.

Cohen, A. (2006). The relationship between multiple commitments and organizational citizenship behavior in Arab and Jewish culture. Journal of Vocational Behavior, 69(1), 105-118.

Cohen, A. (2007). Dynamics between occupational and organizational commitment in the context of flexible labor markets: A review of the literature and suggestions for a future research agenda.

Gea, A. A. (2010). Pengembangan culture, self, and personality Dalam Diri Manusia. Humaniora, 1(1), 37-48.

Gibson, J., Ivancevich, J., \& Donelly, J. (2015). Manajemen Sumber Daya Manusia.

He, H., Wang, W., Zhu, W., \& Harris, L. (2015). Service workers' job performance: The roles of personality traits, organizational identification, and customer orientation. European Journal of Marketing, 49(11/12), 1751-1776.

Yang, C. L., \& Hwang, M. (2014). Personality traits and simultaneous reciprocal influences between job performance and job satisfaction. Chinese Management Studies, 8(1), 6-26.

Ivancevich, K. M. (2011). Organizational Behavior and Management. New York: McGraw Hill.

Kalkavan, S., \& Katrinli, A. (2014). The effects of managerial coaching behaviors on the employees' perception of job satisfaction, organisational commitment, and job performance: Case study on insurance industry in Turkey. Procedia-Social and Behavioral Sciences, 150, 1137-1147.

Kambu, A., Troena, E. A., \& Setiawan, M. (2012). Influence of leader-member exchange, perceived organizational support, Papua ethnic culture and organizational citizenship behavior toward employee performance of workers in Papua provincial secretary office, 5(4), 31-38.

Kashefi, M., Adel, R. M., Abad, H. R. G., Aliklayeh, M. B. H., Moghaddam, H. K., \& Nadimi, G. (2013). Organizational commitment and its effects on organizational performance. Interdisciplinary journal of contemporary research in business, 4(12), 501-510.

Krajewski, H. T., Goffin, R. D., Rothstein, M. G., \& Johnston, N. G. (2007). Is personality related to assessment center performance? That depends on how old you are. Journal of Business and Psychology, 22(1), 21-33.

Kreitner, R., \& Kinicki, A. (2014). Organizational behavioral. 
Kwantes, C. T. (2009). Culture, job satisfaction and organizational commitment in India and the United States. Journal of Indian Business Research, 1(4), 196-212.

Liguori, E., D. McLarty, B., \& Muldoon, J. (2013). The moderating effect of perceived job characteristics on the proactive personality-organizational citizenship behavior relationship. Leadership \& Organization Development Journal, 34(8), 724-740.

Lin, Z., \& Zhao, Z. (2016). Culture, expatriation and performance: case of Chinese multinational enterprises. Chinese Management Studies, 10(2), 346-364.

Liu, Y., Bao, Y., \& Liu, W. (2013). Mapping the values and culture in Chinese public sectors: an exploratory study. Cross Cultural Management, 20(4), 559-577.

Mallak, L. A., Lyth, D. M., Olson, S. D., Ulshafer, S. M., Ulshafer, S. M., \& Sardone, F. J. (2003). Culture, the built environment and healthcare organizational performance. Managing Service Quality: An International Journal, 13(1), 27-38.

Mandagi, F. M., Umboh, J. M. ., \& Ratu, J. a. . (2015). Analisis Faktor - Faktor Yang Berhubungan Dengan Kinerja Perawat Dalam Menerapkan Asuhan Keperawatan Di Rumah Sakit Umum Bethesda Gmim Tomohon. Jurnal E-Biomedik (EBm), $3,1-11$.

Mannion, R., Davies, H. T. O., \& Marshall, M. N. (2005). Cultural characteristics of "high" and "low" performing hospitals. Journal of Health, Organisation and Management, 19(6), 431-439.

Matsumoto, D. (2007). Culture, context, and behavior. Journal of personality, 75(6), 1285-1320.

Meyer, J. P., Allen, N. J., \& Smith, C. A. (1993). Commitment to organizations and occupations : Extension and Test of a, 78(4), 538-551.

Muda, I., Rafiki, A., \& Harahap, M. R. (2014). Factors influencing employees’ Pperformance: A study on the Islamic banks in Islamic science of Malaysia university of North Sumatera. International Journal of Business and Social Sience, 5(2), 73-81.

Ngo, H. Y., \& Li, H. (2015). Chinese traditionality and career success: mediating roles of procedural justice and job insecurity. Career Development International, 20(6), 627-645.

Rante, Y. (2010). Pengaruh Budaya Etnis dan Perilaku Kewirausahaan Terhadap Kinerja Usaha Mikro Kecil Agribisnis di Provinsi Papua. Jurnal Manajemen Dan Kewirausahaan, 12, 133-141.

Rarick, C. A. (2007). Confucius on Management: Understanding Chinese Cultural Values and Managerial Practices, (August), 22-28.

Rashid, Mohd, N., Farhana, N., Sah, M., \& Mohd, N. (2016). The Influence of Bank's Frontlines ' Personality Traits on Job Performance. Procedia Economics and Finance, 37(16), 65-72.

Robbins, S. (2008). Perilaku Organisasi. (B. Pujaatmaka, Hadyana; Molan, Ed.) (8th ed.). New Jersey: Prentice Hall.

Sahusilawane, F. (2004). Sejarah Lahirnya Pela dan Gandong Antar Negeri-negeri Di Pulau Ambon. Laporan Penelitian Sejarah dan Nilai Tradisional Ambon. Ambon.

Secim, H. (2015). Organizational commitment and perceived organizational performance among health care professionals : Empirical evidence from a private hospital in Northern Cyprus, 7(1), 64-71.

Soane, E., Butler, C., \& Stanton, E. (2015). Followers' personality, transformational leadership and performance. Sport, Business and Management: An International Journal, 5(1), 65-78.

Teasdale, B. A. (1999). Japanese Tradition and Culture: Aid or Obstacle to Future Success? In Japanese Tradition and Culture : Aid or Obstacle to Future Success?

Tolentino, R. C. (2013). Organizational commitment and job performance of the academic and administrative personnel. International journal of Information technology and Business Management, 15(1), 51-59.

Triandis, H. C., \& Suh, E. M. (2002). Cultural influences on personality. Annual review of psychology, 53(1), 133-160.

Uneputty, T. J. (1996). Perwujudan Pela Dalam Kehidupan Sosial Masyarakat Maluku. Ambon: Bagian Proyek Pengkajian dan Pembinaan Nilai-Nilai Budaya Maluku.

Wahyuni, S. (2008). Analisis pengaruh komitmen organisasional pada kinerja perawat pavilliun cendana rumah sakit Dr . Moewardi Surakarta.

Widyaningrum, M. E. (2012). Effects of organizational culture and ability on organizational commitment and performance In Ibnu Sina Hospital Gresik. Academic Research International, 2(1), 349-355.

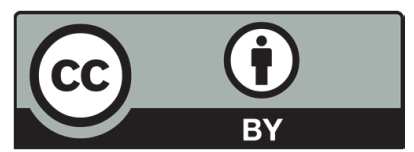

(C) 2020 by the authors; licensee Growing Science, Canada. This is an open access article distributed under the terms and conditions of the Creative Commons Attribution (CC-BY) license (http://creativecommons.org/licenses/by/4.0/). 